\title{
Benign Adult Cerebellar Neoplasm
}

National Cancer Institute

\section{Source}

National Cancer Institute. Benign Adult Cerebellar Neoplasm. NCI Thesaurus. Code C5796.

A benign neoplasm of the cerebellum occurring in adults. 